\title{
Luigi Derla, «Balzac e il romanzo storico: Une Ténébreuse Affaire»
}

\section{Marco Stupazzoni}

\section{(2) OpenEdition}

1 Journals

\section{Edizione digitale}

URL: https://journals.openedition.org/studifrancesi/26527

DOI: $10.4000 /$ studifrancesi.26527

ISSN: 2421-5856

\section{Editore}

Rosenberg \& Sellier

\section{Edizione cartacea}

Data di pubblicazione: 1 avril 2007

Paginazione: 193

ISSN: 0039-2944

\section{Notizia bibliografica digitale}

Marco Stupazzoni, «Luigi Derla, «Balzac e il romanzo storico: Une Ténébreuse Affaire»», Studi Francesi [Online], 151 (LI | I) | 2007, online dal 30 novembre 2015, consultato il 23 novembre 2021. URL: http:// journals.openedition.org/studifrancesi/26527 ; DOI: https://doi.org/10.4000/studifrancesi.26527

Questo documento è stato generato automaticamente il 23 novembre 2021.

\section{(c) (i) (9)}

Studi Francesi è distribuita con Licenza Creative Commons Attribuzione - Non commerciale - Non opere derivate 4.0 Internazionale. 


\title{
Luigi Derla, «Balzac e il romanzo storico: Une Ténébreuse Affaire»
}

\author{
Marco Stupazzoni
}




\section{NOTIZIA}

LUIGI DERLA, «Balzac e il romanzo storico: Une Ténébreuse Affaire», in «Testo. Studi di teoria e storia della letteratura e della critica», n. 49, nuova serie, anno XXVI, gennaiogiugno 2005, pp. 67-82.

1 In Une Ténébreuse Affaire, la breve distanza che intercorre tra il tempo dell'azione (1803-06) e quello della scrittura (1841) contribuisce a connotare l'opera balzachiana di una spiccata originalità e di uno specifico valore storico e ideologico. Il romanzo in questione costituisce infatti uno degli esempi più significativi dell'attenzione costante che Balzac dedicò allo studio delle trasformazioni della società sua contemporanéité: la ricostruzione dettagliata delle oscure vicende storiche legate al rapimento del senatore Clément de Ris nel 1800 rappresenta, per lo scrittore, l'occasione forse unica per indagare e denunciare la crisi profonda delle istituzioni politiche e sociali sorte dalle ceneri della Rivoluzione e fondamento della nuova società borghese.

2 In questo saggio, le lucide riflessioni di Luigi Derla su questo ultimo romanzo storico della Comédie humaine - dove Balzac recupera alcuni modelli scottiani per poi riformularli e ricomporli in forme e strutture narrative nuove che annunciano già quelle del futuro romanzo poliziesco - ci consentono di cogliere gli aspetti essenziali del pensiero politico balzachiano e di valutare allo stesso tempo la funzionalità dell'alto coefficiente narrativo che caratterizza la vicenda storica narrata. Ultimo «romanzo storico possibile», Une Ténébreuse Affaire «predice l'imminente fine della Storia», poiché, secondo Balzac, ciò che viene dopo l'Impero rappresenta soltanto «l'assentarsi del concetto stesso di "Storia"» (p.81) che fino ad allora aveva trovato in se stessa il proprio senso, anche filosofico, grazie ad eventi, istituzioni e figure altamente rappresentativi. 